BEATA LORENS

UNIWERSYTET RZESZOWSKI

\title{
MUZYKA W DZIAŁALNOŚCI DUSZPASTERSKIEJ BAZYLIANÓW W RZECZYPOSPOLITEJ W XVIII WIEKU
}

\footnotetext{
$Z$
} akon Ruski św. Bazylego Wielkiego (Ordo Sancti Basilii Magni Ruthenorum) należał w XVIII w. do najliczniejszych zgromadzeń męskich w Rzeczypospolitej, chociaż jego placówki usytuowane były głównie na ziemiach litewskich i ruskich. Pod względem podziału administracyjnego składał się z dwóch prowincji oraz archimandrii supraskiej bezpośrednio podporządkowanej metropolicie unickiemu. Mimo tradycji mniszej po reformach metropolity Józefa Welamina Rutskiego przeprowadzonych w pierwszym dwudziestoleciu XVII w. zakon upodobnił się, zwłaszcza co do działalności, do łacińskich zakonów kleryckich. Spełniał ważne funkcje duszpasterskie, prowadząc parafie przy swoich cerkwiach, opiekując się sanktuariami oraz rozwijając pobożność wiernych poprzez różnorakie formy nabożeństw. Działalność duszpasterska w parafiach zakonnych była o wiele bogatsza niż w cerkwiach prowadzonych przez duchowieństwo diecezjalne ze względu na większą liczbę nabożeństw liturgicznych i paraliturgicznych. Oprócz Służby Bożej odprawiano nieszpory, śpiewano litanie i hymny. Wprowadzano nabożeństwa poświęcone świętym oraz wydarzeniom zbawczym. W Krystynopolu w każdy poniedziałek po rannej mszy św. odprawiano nabożeństwo ku czci św. Onufrego, złożone z litanii do tego patrona i śpiewu pieśni jemu poświęconych oraz wprowadzono nabożeństwo do Męki Pańskiej, podczas którego oddawano cześć krzyżowi². Okresem wzmożonej działalności duszpasterskiej były święta patronalne cerkwi bazyliańskich, w czasie których udzie-

I Beata Lorens, Bazylianie prowincji koronnej w latach 1743-I780, Rzeszów 20I4, s. 235-254.

2 Lwowska Narodowa Naukowa Biblioteka im. W. Stefanyka, Oddział Rękopisów (dalej cyt.: LNNB), f. 3 - Centralne Bazyliańskie Archiwum i Biblioteka w Lwowie, od. zb. 802 - Dziejopis monasteru krystynopolskiego ZSBW od R.P. I766, k. I5, I7, I35v; Centralne Państwowe Archiwum Historyczne Ukrainy we Lwowie (dalej cyt.: CPAHL), f. 684 - Protoihumenat klasztorów Zakonu św. Bazylego Wielkiego we Lwowie, op. I, sp. 3075 - Inwentarzowy opis ruchomego i nieruchomego majątku w Krystynopolu I766-I786, k. 22v-23; Biblioteka OO. Bazylianów w Warszawie (dalej cyt.: BBW), sygn. Krystynopol $28-$ Akta Parochyi Krystynopolskiey do cerkwi Krystynopolskiey Zakonu S. Bazylego W. należącego od R.P. 1766 zaczęte, b.p. 
lano przybyłym wiernym odpustów pozyskanych w Stolicy Apostolskiej. Z tej okazji zapraszano też kaznodziejów, przeważnie zakonników ze zgromadzeń rzymskokatolickich, organizowano uroczyste procesje, dysputy oraz koncerty.

W działalności duszpasterskiej wielką rolę odgrywała muzyka. Była tym czynnikiem, który przyciągał wiernych do danej świątyni. W połowie XIX w. proboszcz cerkwi bazyliańskiej w Lublinie skarżył się, że zbierano się tłumnie na nabożeństwa tylko wtedy, gdy towarzyszyła im muzyka³. Uświetnianie nabożeństw liturgicznych wymagało odpowiedniej oprawy, którą zapewniali śpiewacy, czyli kantorzy oraz organiści.

W teologii i tradycji chrześcijańskiego Wschodu istotą muzyki cerkiewnej jest muzyka wokalna. Zasada ta wynikała z ascetyzmu i supremacji słowa, które miało kształcić odpowiednią duchowość i pobożność wiernych. Zadaniem muzyki cerkiewnej było zatem uwypuklanie tekstów liturgicznych, stąd słowo i muzyka musiały tworzyć spójną całość. Początkowo śpiew liturgiczny wykonywany był monodycznie. W XVII w. Cerkiew wprowadziła do liturgii śpiew wielogłosowy, przy czym kontakt $\mathrm{z}$ tego typu śpiewem na terenach wschodniosłowiańskich miał miejsce już w XII w. ${ }^{4}$. Dla ziem ruskich Rzeczypospolitej charakterystycznym śpiewem wielogłosowym (polifonicznym) był śpiew partesny (partesowy), który łączył tradycje muzyczne Wschodu z elementami kultury muzycznej Zachodu. Po przyjęciu unii brzeskiej w I596 r. ta właśnie muzyka miała być magnesem przyciągającym wiernych do nowego obrządku. Rywalizacja wyznaniowa sprawiła, że Cerkiew unicka przyjęła śpiew wielogłosowy rozpowszechniony na ziemiach ruskich Rzeczypospolitej. Doszło do połączenia zachodniego systemu muzyki z prawosławnym śpiewem liturgicznyms.

Wspólnota bazyliańska opierająca się w swej duchowości na naukach św. Bazylego Wielkiego stosowała się do jego wskazówek zawartych w Regutach dtu̇̇szych i Regutach krótszych. Polecał w nich odmawianie lub śpiewanie psalmów w określonych porach dnia i nocy, tworząc zasady wspólnej modlitwy braci (psalmodii). Św. Bazyli Wielki powtarzał za Księgą Psalmów nakaz: „Śpiewajcie psalmy rozumnie”, co tłumaczył jako odpowiednie usposobienie duszy do zrozumienia sensu każdego słowa $^{6}$. Do obowiązków profesów bazyliańskich należało uczestnictwo w modlitwie chórowej. We wszystkich cerkwiach bazyliańskich znajdowały się chóry zakonne,

3 „W niedzielę przeszłą [ı3 IX I848 r.] P. Rajczak sławny artysta warszawski w przejeździe z swoją orkiestrą odegrał summę uniacką w naszym kościele, na której było pełen kościół publiczności lubelskiej wyższego stanu", zob.: Archiwum Państwowe w Lublinie (dalej cyt.: APL), zespół III/3 - Klasztor Bazylianów w Lublinie, sygn. 4 - Akta dotyczące sktadania różnych wykazów I840-I85I, s. 26; zespół 95 - Chełmski Konsystorz Greckokatolicki, sygn. 387 - Akta gruntowe tyczące się cerkwi parafialnych. Dekanat lubelski. Parafia Lublin (bazyliańska) I8I7-I86I, k. I02v-I03.

4 Włodzimierz Wołosiuk, Wschodniostowiańscy kompozytorzy muzyki cerkiewnej od XVII do I. potowy XX wieku i obecność ich utworów w nabożeństwach PAKP, Warszawa 2005, s. IO-I4.

5 Leszek Mazepa, „Życie muzyczne dawnego Lwowa (XIII-XVII wiek)”, Musica Galiciana I (I997) s. I7-I9.

6 Św. Bazyli Wielki, Pisma ascetyczne, t. 2, Reguty dtuższe. Reguty krótsze, przekł. i opr. Jan Naumowicz, Tyniec-Kraków 1995 (= Źródła monastyczne 6), s. I48-I5I, 4I8-419. 
sytuowane często za lub przed wielkim ołtarzem oraz przed ołtarzami bocznymi. Nakaz brania udziału we wspólnotowej modlitwie zawierał Summariusz regut Świętego Ojca Naszego Bazylego Wielkiego z regut obszerniejszych i krótszych, z konstytucji mniskich $i$ nauk Jego zakonnych wkrótce zebrany wydany w Poczajowie w I75I r. ${ }^{7}$ Nakaz ten był wielokrotnie przypominany w zaleceniach powizytacyjnych w II poł. XVIII wieku. Zakonników z archimandrii w Supraślu w I762 r. informowano, że „śpiewanie w chórze ma być z wolna, poważne, bez wytworności, tonem pomiernym, zgodliwie tak co do głosów na obydwóch chórach, jako też co do ustawu"8. W XVII w. stosunek zakonników do muzyki był przedmiotem rozważań podejmowanych podczas kapituł zakonnych. Profesom nakazywano unikać muzyki świeckiej, zarówno w klasztorze, jak i poza nim. Traktowano ją jako rozrywkę niezgodną z duchem zakonnej ascezy ${ }^{9}$. Sami zakonnicy surowo oceniali tych współbraci, którzy życie wspólnoty monastycznej zakłócali muzyką świecką. O. Błażejowi Duczakiewiczowi, rektorowi kolegium w Hoszczy, zarzucali, że „pieśni kozackie szpetne śpiewa oraz w klasztorze grać i tańcować każe”ı. W życiu niektórych monasterów była natomiast obecna muzyka religijna, np. w klasztorze w Buczaczu z okazji świąt Bożego Narodzenia uczniowie tamtejszego kolegium odwiedzali z kolędą zakonników w ich celach. Jak odnotowano, „chodzili z muzyką” ${ }^{\prime I}$.

W XVI-XVII w. monastery, obok bractw cerkiewnych, były tym środowiskiem, w którym rozwijała się kultura muzyczna ${ }^{\mathrm{I2}}$. Prawosławne klasztory bazyliańskie w XVII w. były ośrodkami przepisywania ksiąg liturgicznych zawierających zapis nutowy jednogłosowego śpiewu wykonywanego podczas nabożeństw, czyli irmologionów (irmołoj). Irmologiony stanowiły zbiór śpiewów hymnograficznych przeznaczonych na święta i uroczystości. Były praktycznymi podręcznikami do nauki śpiewu cerkiewnego i podstaw muzyki ${ }^{\mathrm{I} 3}$. Początkowo umiejętności te kształcono również

7 Summariusz regut Świętego Ojca Naszego Bazylego Wielkiego z regut obszerniejszych i krótszych, z konstytucji mniskich i nauk Jego zakonnych wkrótce zebrany, Poczajów I75I, s. 64-65, I25, I27.

8 Radosław Dobrowolski, „Klasztor księży Bazylianów supraskich w latach 6o. i 70. XVIII w. Kryzys czy upadek?”, w: Mate miasta. Między tradycją a wyzwaniem przysztości, red. Mariusz Zemło, Supraśl 2002 (= Acta Collegii Suprasliensis 2), s. I36.

9 Rozporządzenie uchwalone na kongregacji XVII w Wilnie w I667 r. nakazywało: „przy napojach muzyki i instrumencistów żadnych nie zażywali”, zob.: Arheografičeskij sbornik dokumentov otnosjaščihsja $k$ istorii severo-zapadnoj Rusi izdavaemyj pri upravlenû Vilenskago Učebnago Okruga, t. XII, Vil'na I90o, s. 98.

IO Archiwum Polskiej Prowincji Dominikanów w Krakowie (dalej cyt.: APPD), Ławra Poczajowska, sygn. 2 Skrutynia, k. 4Iv.

II LNNB, f. 5- zespół Ossolińskich, dz. I, od. zb. 6196 - Diarium actorum Collegij Buczacensis connotatorum per Patrem Hieronymum Nereziusz I750, k. 63v.

I2 O roli bractw cerkiewnych w rozwoju muzyki pisał Jarosław Isajewicz, zob.: Âroslav Isaêvič, „Bratstva i ukrains'ka muzična kul'tura XVI-XVIII st.", Ukrains'ke muzikoznavstvo 6 (I97I), s. 48-57.

I3 Jurij Jasinowskij, „Znaczenie eparchii przemyskiej w rozwoju ukraińskiej muzyki cerkiewnej”, w: Polska - Ukraina. Iooo lat sąsiedztwa, t. 2, Studia z dziejów chrześcijaństwa na pograniczu kulturowym i etnicznym, red. Stanisław Stępień, Przemyśl I994, s. 405-407; Mihajlo Šved, Spas'kij ta Lavrivs'kij monastiri - oseredok duhovnosti i kul'turi v Galičini, L'viv 2000, s. 90-93. 
w unickich monasterach bazyliańskich. Pod koniec lat trzydziestych XVIII w. jako jarmołoiści zostali określeni brat Gedeon z Lipowca w monasterze w Szczepłotach, o. Mardary Dobrosiński w monasterze w Pacykowie oraz o. Tarazy Juszczyk z Kryłosa (rezydencja pw. św. Eliasza) ${ }^{14}$. Wnioskować więc można, że trudnili się oni przepisywaniem zapisu nutowego oraz byli obznajomieni ze sztuką wykonywania tego typu utworów. $Z$ biegiem czasu umiejętność przepisywania irmologionów traciła na znaczeniu i nie była rozwijana, najprawdopodobniej z powodu wzrostu dostępności ich drukowanych wersji. W II poł. XVIII w. nie odnotowywano obecności jarmołoistów w społeczności zakonnej prowincji koronnej. W połowie XVIII w., charakteryzując poszczególnych zakonników, władze prowincji koronnej zaznaczały ich umiejętności w dziedzinie śpiewu ${ }^{\text {Is. }}$. Bardzo rzadko odnotowywano jednak szczególne umiejętności w tym zakresie. Tak było w przypadku o. Nikodema Ożomylskiego (Ożomielskiego) w monasterze w Czernilawie, o którym zapisano: „ośmiohłasnik śpiewał, głos nie zgorszy ma"16.

W II poł. XVIII w. kultura muzyczna wydawała się lepiej rozwijać w bazyliańskiej prowincji litewskiej. W szematyzmie tej prowincji z I754 r. w sześciu placówkach wymieniano zakonników określanych jako „prefekt muzyki”: Boruny (o. Jakub Trusiewicz), Chełm (o. Merkury Stanisławski), Jatwiesk (o. Stefan Wiszniewski), Kobryń (o. Tadeusz Kmita), Wilno (o. Marcel Butharowski), Żyrowice (o. Onufry Obrządkiewicz ${ }^{17}$. W analogicznym czasie w prowincji koronnej takiej funkcji nie odnotowano, co nie świadczy o istnieniu tam muzycznej „pustyni”. Pod koniec lat trzydziestych XVIII w. jako prefekt muzyki w rezydencji bazyliańskiej przy katedrze unickiej w Łucku występował o. Gedeon Dembczyński ${ }^{18}$. W II poł. XVIII w. funkcja regensa muzyki wykonywana była w monasterze w Poczajowie. Pełnił ją wówczas ojciec Tarazy Tarnawski, bardzo zasłużony dla rozwoju muzyki w bazyliańskiej prowincji koronnej ${ }^{19}$. Ten zakonnik, pochodzący z Kańczugi, urodzony w 1725 r., ochrzczony jako Tymoteusz, wstąpił do zakonu bazyliańskiego w Dobromilu w 1753 r., a rok później złożył profesję oraz przyjął święcenia kapłańskie ${ }^{20}$. Kierował on kapelą

I4 Państwowe Archiwum Obwodu Tarnopolskiego (dalej cyt.: PAOT), f. 258 - Ławra Poczajowska, op. 3, sp. II94 - Sktad osobowy monasterów bazyliańskich za lata $1737-1740$, k. 26, 35v, 37v.

I5 APPD, Ławra Poczajowska, sygn. 2, passim. Umiejętności zakonników określano terminami: „śpiewa dobrze”, „głosu pomiernego”, „głosista”, „śpiewa niezgorzej”, „śpiewa doskonale”, „głos dobry ma”, „głos niezgorszy ma”.

I6 Ibid., k. IIo. Ośmiohłasnik (oktoich) to księga liturgiczna zawierająca zbiór hymnów św. Jana z Damaszku.

17 Catalogus Personarum Ordinis S. Basilii M. in Provincia Lithuana s. t. SSmae Trinitatis Deo militantium A.D. I754 die Ima Septembris ut novum confectus, w: Mihajlo Miroslav Vavrik, Naris rozbitku i stanu vasilijans'kogo čina XVII-XX st. Topografično-statistična rozvidka, Rim 1979 (= Analecta OSBM, series II, sectio I, vol. 40), s. 84-IOI.

I8 PAOT, f. 258 , op. 3 , sp. II94, k. Iо.

I9 CPAHL, f. 684, op. I, sp. 327I - Ksiegga wydatków monasteru w Poczajowie 1772-I789, k. 59v.

20 LNNB, f. 3 , od. zb. 436 - Cathalogus Alphabeticus specificans unius cujusque nomen, cognomen tum suum Religiosum, t. III, k. I47; Catalogus Professorum Ordinis S.B. Magni Provinciae Protectionis Beatissimae Virginis Mariae [...] ex Anno 1778 in Annum 1779, Poczajów I778, b.p. 
funkcjonującą przy klasztorze w Poczajowie, dbał o jej odpowiednie wyposażenie w stroje i instrumenty muzyczne oraz dobierał repertuar. Z kolei funkcję kapelmistrza kapeli działającej w Uniowie pełnił o. Abraham Hulewicz, bazylianin, należący do małej grupy członków tego zakonu trudniących się muzyką. Hulewicz, noszący imię chrzestne Antoni, urodził się w I7I2 r. w Jaworowie. Do nowicjatu bazyliańskiego w Poczajowie wstąpił już jako „słynny muzyk” w $1743 \mathrm{r}^{2 \mathrm{I}}$.

W XVIII w. po reformach synodu zamojskiego Cerkiew unicka zaczęła posługiwać się muzyką instrumentalną. Bazylianie byli prekursorami, jeśli chodzi o jej wprowadzanie do liturgii. Warto jednak zauważyć, że oprawa taka towarzyszyła sytuacjom wyjątkowym, związanym z wydarzeniami, w których udział brali wierni różnych obrządków. W codziennym funkcjonowaniu społeczności zakonnej muzyka instrumentalna praktycznie nie występowała.

Władze bazyliańskiej Kongregacji Trójcy Świętej wspominały o „muzyce” przy cerkwi Trójcy Świętej w Wilnie już podczas II kapituły bazyliańskiej w Ławryszowie w I62I r. ${ }^{22}$. Podczas kapituły w 1709 r. zalecano utrzymywanie przy monasterze w Wilnie kapeli, „z której znaczny idzie klasztorowi pożytek”, najpewniej finansowy ${ }^{23}$. Zgodnie z tą wskazówką przy klasztorze funkcjonowała kapela wraz z bursą muzyczną. W 1. 1724-28 jej seniorem był Andrzej Wojnarowicz, zaś od marca 1728 r. - Łukasz Śliwczyński. Do bursy przyjmowano kilkuletnich chłopców, którzy przez pięć do dziesięciu lat uczyli się gry na różnych instrumentach oraz śpiewu, a po zakończeniu nauki mieli obowiązek taki sam czas uczyć następnych. Mieszkali oni na terenie klasztoru, zaś w czasie wolnym od zajęć mogli uczęszczać do Akademii Wileńskiej „dla nauk szkolnych”. Członkom kapeli wypłacano pensję (I5o złp rocznie) oraz oddawano elementy garderoby (kontusz szarak) czy obuwia (para butów z przyszwami). Obok gry i śpiewu w cerkwi kapeliści i bursiści byli zobowiązani wypełniać zobowiązania muzyczne poza klasztorem ${ }^{24}$. I9 II 1727 r. magistrat wileński zawarł kontrakt z kapelą bazyliańską w sprawie grania z wieży ratuszowej o określonych godzinach w ciągu dnia przez dwóch trębaczy. W kontrakcie sprecyzowano terminy usługi:

[...] od Wszystkich SS. do S. Jerzego dwa razy na dzień z rana o piątej, a drugi ku południowi o jedenastej godzinie. A od S. Jerzego do Wszystkich SS. letniego czasu trzy razy na dzień, raz z rana o czwartej, drugi ku południowi o jedenastej, trzeci z wieczora

LNNB, f. 3, od. zb. 378 - Katalog WW. OO. Bazylianow stynacych nauka i cnota w Polszcze utożyt ksiadz Sadok Baracz, k. 47.

22 Arheografičeskij sbornik dokumentov, op. cit., t. XII, s. 2I; Porfirij Pidručnij, Bogdan Pêtnočko, Vasilijans'ki general'ni kapituli vid I6I7 po I636 rik, t. I, Rim-L'viv 2017 (= Analecta OSBM, series II, sectio I, vol. 53), s. I43. O tradycji muzycznej w środowisku unickim w Wilnie w XVII w. zob.: Ivan Kuz’mins’kij, „Istorija cerkovnoj muziki kriz' prizmu dijal'nosti ukraino bilorus'kich mitropolitiv ta êpiskopiv I7 stolittja” (artykuł w druku). Bardzo dziękuję autorowi za jego udostępnienie.

23 Arheografičeskij sbornik dokumentov, op. cit., t. XII, s. I6I.

24 CPAHL, f. 684, op. I, sp. 3290 - Rejestr instrumentów muzycznych, kontrakty z dyrygentami i cztonkami kapeli, rejestry dochodów i wydatków monasteru $w$ Wilnie z lat I72I-I734, k. 2-IO. 
o siódmej do święta Wniebowzięcia N. Panny, a od święta immediate pomienionego aż do Wszystkich SS. o godzinie szóstej według zegara ratuszowego.

Kontrakt przewidywał wypłatę I7o złp rocznie dwoma ratami oraz oświetlenie wejścia na wieżę. Dodatkowo w święta Bożego Narodzenia i Wielkanocy, obchodzone według obu kalendarzy, cała kapela miała grać przez trzy dni, za co otrzymywała za każde święto 4 talary bite ${ }^{25}$.

W XVIII w. kapela przy klasztorze Trójcy Świętej w Wilnie posiadała bogaty zespół instrumentów muzycznych. Według rejestru z I73I r. w monasterze znajdowało się sześć trąbek, cztery waltornie, puzon, trzy oboje, cztery fagoty, wiola, pięcioro skrzypiec, dwa klawikordy ${ }^{26}$. Inwentarz klasztoru przy cerkwi Trójcy Świętej sporządzony 24 II I774 r. z polecenia prowincjała litewskiego Sylwestra Arteckiego z okazji objęcia funkcji przełożonego przez Joachima Czudowskiego zawierał spis pięćdziesięciu siedmiu sztuk starszych i nowych instrumentów. Skrzypce, w liczbie dziesięciu sztuk, pochodziły z renomowanych warsztatów lutniczych w Niemczech, m.in. Carla Wilhelma Hebera i Carla Friedricha Pfretzschnera. Ponadto instrumentarium stanowiły wiole, altówka, basetle, trąbki, waltornie, puzon, oboje, flety ${ }^{27}$. Obok instrumentów muzycznych w inwentarzu odnotowano „papiery muzyczne” w I89 egzemplarzach. Wśród nich przeważały partytury utworów religijnych związanych z zachodnią kulturą muzyczną, np. utwory niemieckiego benedyktyna Lamberta Krausa (1728-90), również niemieckiego benedyktyna Gregora Schreyera (I719-67) i jego ucznia Nonnosiusa Madlsedera (I730-97), Isfrida Kaysera (I712-71), Friedricha Hartmanna Grafa (I727-95) lub jego brata Chrystiana Ernesta Grafa (I723-I804), włoskiego kompozytora Giovanniego Battisty Pergolesiego (I7IO-36) ${ }^{28}$. Ponadto wymieniano liczne egzemplarze mszy łacińskich, mszy żałobnych łacińskich i ruskich, nieszporów w obu obrządkach, litanii. Muzykę cerkiewną reprezentowały Pryczasnik Ruski i Kanony woskresne. Wśród tych partytur znalazł się także zbiór arii łacińskich o nieokreślonym charakterze (religijnych bądź świeckich). Część tego zbioru była pisana, ale znaczną liczbę stanowiły druki, najpewniej wydane w typografii działającej przy klasztorze. Na jej wyposażeniu były „linie dla nut” i „znaki nutowe”, co potwierdzałoby wydawanie przez wileńskich bazylianów dzieł muzycznych ${ }^{29}$. Kapela bazylia-

25 Ibid., k. 4v.

26 Ibid., k. 2v.

27 Mikoła Nikołajew, „Drukarnia klasztoru św. Trójcy w Wilnie w świetle nowych dokumentów archiwalnych", w: Ksiażka ponad podziatami, red. Antoni Krawczyk, Lublin 2007, s. I78-I8I. Autor zamieścił w tabeli nr I tekst źródłowy odnaleziony w Archiwum Petersburskiego Instytutu Historii Akademii Nauk Rosji.

28 Ibid., s. I8r. M.in.: „Litanij Krawsa 8. Drukowanych xiązek oprawionych w papier Tyrecki głosow - I2”; „Mszy Krawsa 8. Drukowanych xiązek także oprawnych w tych ze książach nieszpory Szkrejera na głosow - 9”; „Synfonij Krawsa drukowanych ksiązek - 6”; „Synfonij Grafa 6 xiązek - 6”; „Stabat Mater Pergolesego sztuka - I”; „Miserere Medlesedera 5 y Stabat Mater dolorosa xiązek drukowanych oprawnych - II".

29 Ibid., s. I77-I8I. 
nów wileńskich podczas procesji i uroczystości religijnych przygrywała z balkonu reprezentacyjnej bramy prowadzącej do klasztoru i cerkwi Trójcy Świętej, wzniesionej przez Jana Krzysztofa Glaubitza ${ }^{30}$. Również placówka w Żyrowicach, stanowiąca centrum pielgrzymek do koronowanego w I730 r. cudownego obrazu Bogarodzicy, przy której prowadzono jedno z najstarszych bazyliańskich kolegiów publicznych, miała kapelę monasterską. W I772 r. jej instrumentarium składało się z dwóch fletów, fagotu, trzech trąbek i czterech waltorni ${ }^{31}$. Kolejnym monasterem w prowincji litewskiej, przy którym w XVIII w. funkcjonowała kapela, był klasztor w Chełmie. Już w I752 r. w inwentarzu wizytacyjnym odnotowano utrzymywanie przy monasterze ośmiu muzyków, z których jeden (nazwiskiem Murzyński) otrzymywał 200 złp rocznie, dwóch (Dorniewicz i Zaremba) po Ioo złp, zaś pięciu (Kirglowski, Woskiewicz, Smolinski, Sawicki, Stempkowski) wynagradzano odzieżą. Prefektem muzyki w klasztorze był wówczas o. Merkury Staniszewski ${ }^{22}$. Znawcą „sztuki muzycznej” w monasterze chełmskim był także kaznodzieja o. Metrofan Mazanowski, o którym Maksymilian Ryłło w swoim Diariuszu zapisał, że 27 XII 1750 r. na prośbę przedstawicieli magnaterii, zapewne goszczących w klasztorze, śpiewał włoskie arie z towarzyszeniem muzyki instrumentalnej ${ }^{33}$. Sofija Senik, pisząc o monasterze chełmskim, zaznaczała, iż do zorganizowania kapeli przyczynił się ówczesny ihumen Maksymilian Ryłło, późniejszy unicki biskup chełmski i przemyski, który w 1753 r. kupił majątek Parypsy i z jego dochodów zwiększył uposażenie kapeli34. Według informacji z 1793 r., chełmski zespół instrumentalno-wokalny składał się z pięciu kapelistów. Byli to: senior Józef Głowacki, Jan Dąbrowski, Jan Nowicki, Antoni Grabowski oraz wymieniony tylko z nazwiska Szymański. Klasztor posiadał także specjalną fundację pieniężną w kwocie I200 złp, przeznaczoną na opłacenie trębaczy ${ }^{35}$.

W bazyliańskiej prowincji koronnej w II poł. XVIII w. odnotowano w źródłach działalność kapeli przy dwóch placówkach zakonnych. Pierwsza z nich funkcjonowała przy klasztorze w Poczajowie. W I773 r. w księdze wydatków tego monasteru odnotowano dziesięć-jedenaście osób związanych z kapelą. Byli to zarówno zakonnicy, jak

Dorota Wereda, „Kult Jozafata Kuncewicza w XVIII wieku”, Acta Academiae Artium Vilnensis 54 (2009), s. 92. Dariusz Ciołka, Latynizacja Kościoła unickiego w Rzeczypospolitej po synodzie zamojskim, Białystok 2014, s. 244. Österreichische Nationalbibliothek in Wien, Handschriftensammlung, Cod. Ser. n. 3848 - Visitationum monasteriorum a R[everendissi]mo Joanne Lukianowicz (I75I-I755), k. 38-39v, I70-I7Iv, 276-277, 370-370v. Bardzo dziękuję Ojcu Doktorowi Porfiremu Pidrucznemu z Rzymu za udostępnienie akt wizytacji.

Ibid., k. I70; Holmskaja eparhia i svjatiteli eja po I866 god', sočinil' Antonij S. Petruševič', L'vov I867, s. I43.

4 Sofija Senik, „Holms'kij Vasilijans'kij Monastir (u polovini visimnadcjatogo stolittja)”, w: Zakony i klasztory w Europie Środkowo-Wschodniej X-XX wiek, red. Henryk Gapski, Jerzy Kłoczowski, Lublin I999, s. 367 .

5 APL, zespół III/2 - Akta klasztorów greckokatolickich (bazylianów) woj. lubelskiego - zbiór szczątków zespołów - klasztor bazylianów w Chełmie, sygn. I - Opisanie klasztoru księży Bazylianów chetmskich I793, s. IO, I9; Beata Lorens, „Monaster bazyliański w Chełmie w XVII i XVIII wieku”, w: Przywrócona pamięci. Ikona Matki Boskiej Chetmskiej: ikonografia-kult-kontekst spoteczny, red. Andrzej Gil, Mirosław Kalinowski, Ihor Skoczylas, Lublin-Lwów 2016, s. 312-313. 
i osoby świeckie. Tych pierwszych reprezentowali o. Tarazy Tarnawski i o. Hilarion Łątowski, obaj grający na skrzypcach, oraz o. Besarion Geruszyński określony jako „kapelista” ${ }^{36}$. W'́ród muzyków świeckich byli m.in. dwaj trębacze - Grzegorz Krzywicki i niejaki Bińkowski (wynagradzani odpowiednio kwotami 30 i 33 złp rocznie), oboista Jędrzej Sokołowski (Ios złp), a także śpiewak („głosista”) nazwiskiem Giżycki (otrzymywał 68 złp) oraz niezidentyfikowany „dyszkancista”. Ponadto wymieniano jeszcze nazwiska trzech instrumentalistów, nie podając bliższych szczegółów związanych z ich funkcjami (Antoni Krocki - I58 złp, Sokolnicki - 60 złp, Trocki - I4O złp) ${ }^{37}$. W 1. I776-77 kapelmistrzem był niejaki Żurowski, któremu zlecano komponowanie mszy i nieszporów granych przez kapelę. Jego kwartalna pensja wraz z dodatkami wynosiła 7I złp Is gr. W I777 r. odnotowywano głównie wydatki na pensje dla trębaczy Bińkowskiego i Bazylka, oraz trębacza i oboisty Sokołowskiego. W tym samym czasie do kapeli należał Jakub Paszczyński, któremu wypłacono 40 złp za pół roku. Na podstawie rachunków za odzież można domniemywać, że było wówczas co najmniej czterech kapelistów ${ }^{38}$.

$\mathrm{Na}$ potrzeby kapeli kupowano instrumenty muzyczne (skrzypce, trąbki) i nuty („papiery muzyczne”) ${ }^{39}$. Tarnawski, nazywany regensem muzyki, w styczniu I777 r. pojechał w tej sprawie do Lwowa, gdzie zakupił dwie waltornie (9o złp), dwie trąbki (6o złp), dwa oboje (36 złp), struny do basetli, kalafonię (I złp), oraz oddał do naprawy skrzypce $(72 \mathrm{złp})^{40}$. Również we Lwowie w latach siedemdziesiątych XVIII w. zlecano przepisywanie nut i sporządzanie partytur dla kapeli poczajowskiej ${ }^{41}$. Niestety, nie udało się odnaleźć śladu tychże w inwentarzach biblioteki monasterskiej w Poczajowie. Dla członków kapeli przygotowywano także odpowiednie stroje, nieraz przerabiane z odzieży świeckiej pozostawionej przez zakonników. Przypuszczać zatem można, że kapeliści ubierali się w żupany i kontusze, przepasywali pasami. Ich odzienie podbijano też futrem, sporządzając dla nich „bekieszki” ${ }^{42}$.

W szematyzmach bazyliańskich o. Besariona określano „ad chorum musices”, zob.: Catalogus monasteriorum Ordinis S. Basilii Magni Provinciae Protectionis Beatissimae Virginis Mariae [...] ex Anno 1776 in Annum 1777, w: M.M. Vavrik, op. cit., s. I67.

37 CPAHL, f. 684, op. I, sp. 3271, k. 6-16, 30v.

38 Ibid., k. I9, 50, 52-52v, 53v, 56v-6I.

39 Ibid., k. 7,8 .

40 Ibid., k. 50.

4I Ibid., k. 6v, 7, 40. W I773 r. „,seniorowi u św. Jerzego we Lwowie za przepisanie nut 24 złp.”. W I776 r. „za papiery muzyczne od pożyczenia i przepisania dla kapeli zapłaciło się panu Bogdanowiczowi we Lwowie dwoma razami 35 złp.". Piotr Bogdanowicz był przełożonym (seniorem) kapeli muzycznej lwowskiego biskupa unickiego Leona Szeptyckiego, zob.: Ivan Kuzminskyi, „Account books of the musical chapel of Lviv Uniate Bishop Leon Szeptycki (1760-1779)", Kwartalnik Mtodych Muzykologów UJ 3 (2018) nr 38, s. 9-IO.

42 CPAHL, f. 684, op. I, sp. 3271, k. 36v, 59v. O podobnych zwyczajach związanych z jezuicką bursą muzyczną i kapelą kolegiacką w Jarosławiu pisał Roman Pelczar w artykule „Życie muzyczne w kościołach i klasztorach Jarosławia w XVI-XVIII w.” (Nasza Przesztość 107 (2007), s. 27-28); tegoż, „Muzyka w kolegiacie jarosławskiej w latach I523-I800", Rocznik Stowarzyszenia Mitośników Jarostawia I6 (2005), s. I3. 
Kapela ta uświetniała uroczystości i odpusty cerkiewne w Poczajowie, zwłaszcza w czasie koronacji ikony Matki Bożej w 1773 roku ${ }^{43}$. Przygrywała również za opłatą podczas odpustów w zakonnych świątyniach łacińskich, np. w kościele Pijarów w Złoczowie, a także podczas kolędy i zapustów, a nawet na weselach okolicznej szlachty. Środki finansowe wypracowane w ten sposób zasilały kasę klasztoru44. Wnosić z tego można, że repertuar kapeli nie ograniczał się do utworów religijnych, ale występowały też motywy świeckie, pieśni popularne i stosowne do uroczystości.

Drugim monasterem w prowincji koronnej, przy którym utrzymywano kapelę i rozwijano kulturę muzyczną, była archimandria w Uniowie. W latach czterdziestych XVIII w. działała tam kapela, ale inicjatywa jej zorganizowania należała do metropolity unickiego Atanazego Szeptyckiego, wówczas archimandryty uniowskiego (do 1746 r.). Jej kapelmistrzem był wspomniany już bazylianin o. Abraham Hulewicz. Kapela uniowska z okazji świąt maryjnych dawała całodzienne koncerty. Z okazji święta Przemienienia Pańskiego przygrywała również w monasterze bazylianek w Uniowie ${ }^{45}$. Następca władyki Szeptyckiego na stanowisku archimandryty uniowskiego Ambroży Turzański, sprawujący tę godność w l. 1746-74, również utrzymywał kapelę. Fakt ten pozwala stwierdzić, że zespół muzyczny związany był $\mathrm{z}$ archimandrią, a nie z biskupem noszącym tytuł archimandryty uniowskiego.

Członkowie kapeli mieszkali w przysiółku należącym do folwarku archimandrii, zwanym Kapelówką. Posiadali grunty orne, łąki i ogrody, z czego jednak nie wynikały dla nich żadne obowiązki. W I747 r. członkami kapeli byli: senior Józef Turzański, Jan Dumanowski (Domanowski), Piotr Nowakowski, Kosma Orzechowski, Jan Karpiński i Teodor Kołczewski ${ }^{4}$. W latach sześćdziesiątych XVIII w. Piotr Nowakowski (1762-67) i Jan Dumanowski (1768-68) zostali odnotowani jako członkowie kapeli działającej przy cerkwi św. Jerzego we Lwowie pod patronatem unickiego biskupa lwowskiego Leona Szeptyckiego. Po 1769 r. Dumanowski wrócił do zespołu w Uniowie ${ }^{47}$. Według rozliczeń finansowych z 1. 177I-73 tamtejsza kapela liczyła szesnaście osób. Kierowało nią wówczas dwóch kapelmistrzów: Wencel Hakiel oraz Antoni Lipman. Poza nimi członkami kapeli byli: Murawski regent, Smolnicki regent, Witwicki dyszkant, Sufczyński trębacz, Piechowicz trębacz, Sokołowski oboista, Schulc kapelista, Skibaczewski „fletotrawersista”, Orzechowski kapelista, Kołczewski kapelista,

Przestawna Góra Poczajowska Dawnościq cudów Przenayczystszey Bogarodzicy Panny od Cudownego Jey Obrazu wynikajacych jaśniejąca, tak z wyrażeniem niektórych Jey task, jako też z opisaniem Uroczystego tegoż cudownego Obrazu uwięczenia, w Roku 1773, Poczajów I807, k. 260.

44 APPD, Ławra Poczajowska, sygn. 22 - Księga rachunkowa monasteru w Poczajowie $1745-1789$, k. 76, 78, 9Iv, 94, IO6v. W I775 r. podczas kolęd i zabaw zapustnych uzyskiwano 6-Io złp, zaś z usług świadczonych podczas odpustów i wesel dochód wynosił 35-54 złp.

45 Igor Mic'ko, Svjatouspens'ka Lavra v Unevi (kinec XIII st.-kinec XX st.), L'viv I998, s. 76.

46 CPAHL, f. 201 - Greckokatolicki Konsystorz Metropolitalny we Lwowie, op. 4b, sp. 529 - Wizyty prowincialne klasztorów Zakonu S. Bazylego W. I75I, k. 45v-46. Inwentarz został wydany, zob.: „Vizitacija univs'kogo monastirja 1747 r.", Lavra (1999) nr 4, s. 40.

47 I. Kuzminskyi, op. cit., s. 7-8, II, I2-I3. 
Domanowski kapelista, Grodkowski śpiewak, Kaczyński, chłopiec dyszkancista. Ich wynagrodzenie za dwa lata wynosiło 4.872 złp 4 gr. Zapewne za udział w uroczystościach poza Uniowem kapeli wypłacono w tym okresie I.68I złp 28 gr strawnego ${ }^{48}$. Kapela uniowska brała udział w uroczystości wprowadzenia bractwa Krzyża Świętego do cerkwi bazyliańskiej w Buczaczu w dn. I8-I9 V I754 roku. Wraz z kapelą prywatną Mikołaja Potockiego grała ona nieszpory „ruskie”49.

Kolejna kapela funkcjonowała najpewniej w archimandrii w Supraślu. Za jej istnieniem już w trzeciej ćwierci XVII w. optował Ivan Kuzminskyi ${ }^{\circ}$. Śpiewacy i muzykanci zostali wymienieni w zarządzeniu unickiego metropolity kijowskiego Cypriana Żochowskiego wydanym dla klasztoru w Supraślu w I687 roku. Według niego tamtejszy archimandryta miał utrzymywać sześciu świeckich śpiewaków-muzykantów dla uświetnienia nabożeństw i odpowiedniej oprawy uroczystości ${ }^{I I}$. W inwentarzach tej placówki z początku XIX w. odnotowano instrumenty muzyczne ,jako to: waltorni, trąb, fagotów, hobojów, flautrawersów, klarynettów, skrzypców, altówek, itp. po większej części niezdatnych do użycia znajduje się około sztuk 40". Prawdopodobnie instrumenty te znalazły się w klasztorze w XVIII wieku. Ich obecność w tak dużej liczbie wskazuje na funkcjonowanie kapeli, ale badaczce kultury muzycznej klasztoru w Supraślu Magdalenie Dobrowolskiej nie udało się znaleźć w źródłach z tego okresu potwierdzenia jej funkcjonowania ${ }^{{ }^{2}}$.

Obecność instrumentów muzycznych (po dwie stare mosiężne trąby i waltornie oraz miedziane kotty chórowe) odnotowano na początku XIX w. w inwentarzach klasztoru i cerkwi bazyliańskiej w Białej Podlaskiej. Były one używane dla oprawy muzycznej uroczystych nabożeństw odprawianych w tamtejszej cerkwi, w której przechowywano relikwie błogosławionego wówczas Jozafata Kuncewicza ${ }^{53}$. W inwentarzu monasteru w Zahorowie, spisanym w I752 r., wymieniono znajdujące się w świątyni instrumenty muzyczne: dwie trąbki, dwie waltornie, obój, skrzypce i klawikord. Zostały one określone jako stare, a więc musiały pochodzić co najmniej z I poł. XVIII wieku. Można przypuszczać, że służyły głównie podczas odpustów

48 LNNB, f. I4I - Zbiór A. Czołowskiego, dz. I, od. zb. 507 - Bazylianie - dokumenty do różnych klasztorów, k. IO5v.

49 LNNB, f. 5, dz. I, od. zb. 6196, k. I3.

50 Ivan Kuz’mins'kij, „Muzična praktyka v Suprasl'komu monastiri v rann'omodernij period”, Studii mistectvoznavči (20I8), $\mathrm{nr}$ I (6I), s. 40-4I.

5I [Mikołaj Ratkiewicz], „Kronika Lawry Supraskiej”, w: Arheografičeskij sbornik dokumentov otnosjaščibsja $k$ istorii severo-zapadnoj Rusi izdavaemyj pri upravlenii Vilenskago Učebnago Okruga, t. IX, Vil'na I870, s. 269.

52 Magdalena Dobrowolska, „Materiały do historii kultury muzycznej klasztoru Bazylianów w Supraślu”, w: Śladami unii brzeskiej, red. Radosław Dobrowolski, Mariusz Zemło, Lublin-Supraśl 2010 (= Acta Collegii Suprasliensis io), s. 6I4-6I5.

53 Dorota Wereda, „Klasztor bazyliański w Białej pod panowaniem Austrii (I795-I809)”, Rocznik Bialskopodlaski I3 (2005), s. I2I, I32. 
cerkiewnych 54 . Bogate instrumentarium znajdowało się w II poł. XVIII w. w klasztorze bazyliańskim w Borunach na Litwie. Według spisu z i79I r. były to: klawikord, trzy kotły, dziesięć obojów, cztery klarnety, trzy małe flety, cztery flety traverso, dwa fagoty, trzy basetle, dwie wiole, czternaścioro skrzypiec oraz instrumenty dęte (sześć trąbek, puzon, trzynaście waltorni). W inwentarzu wspomniano również o „papierach muzycznych”, spisanych w latach wcześniejszych. Instrumenty służyły zapewne kapeli i młodzieży uczącej się w tamtejszym kolegium55. W I804 r. w kaplicy przy klasztorze bazyliańskim w Humaniu odnotowano obecność instrumentów chórowych: skrzypiec, basów i dwóch klarnetów ${ }^{56}$. Podobnie w inwentarzu cerkwi bazyliańskiej w Buczaczu z I769 r., gdzie wymieniano dwie pary trąbek mosiężnych, jedną parę waltorni oraz trzy pary kotłów chórowych ${ }^{57}$.

Bardzo często w cerkwiach bazyliańskich z okazji odpustów odprawiali nabożeństwa przedstawiciele duchowieństwa łacińskiego, którym towarzyszyły kapele. Tak było w Dobromilu w 1779 r., gdzie odpust św. Onufrego celebrowali karmelici trzewiczkowi z Sąsiadowic wraz z własną kapelą ${ }^{58}$ Z kolei np. bazylianki z klasztoru w Witebsku w połowie XVIII w. zapraszały do swego klasztoru z okazji obłóczyn oraz odpustów kapelę z klasztoru jezuickiego w tym mieście ${ }^{59}$.

Powyższe informacje pozwalają na konstatację, że przynajmniej przy sześciu monasterach bazyliańskich w XVIII w. funkcjonowały kapele, zaś w pięciu kolejnych klasztorach odnotowano obecność instrumentów muzycznych, sugerujących możliwość bądź to istnienia kapeli, bądź okolicznościowego zatrudniania instrumentalistów. Zestawienie liczby kapel i placówek bazyliańskich (sześć na sto czterdzieści cztery w I772 r. ) nie przynosi imponującego rezultatu, jednak sytuacja wyglądała podobnie w zakonach łacińskich, np. u Paulinów - pięć kapel, Dominikanów - sześćco . XIX w.", Muzyka 35 (1990) nr 2, s. 83-94, zob. s. 88-89. "Sierpień 1750 - za granie na obloczynach u Panien Bazylianek wieży i mszy śpiewanej - I3 zł I5 gr; lipiec I753 - od panien Bazylianek za msze graną pod czas Processyi - Io zł”.

60 Alina Mądry, Barok, cz. 2, I697-I79s Muzyka religijna i jej barokowy modus operandi, Warszawa 2013 (= Historia Muzyki Polskiej 3/2), s. 219-24I, 278-290; tejże, „O muzykowaniu w klasztorach katolickich XVIII-wiecznej Rzeczypospolitej”, w: Przestrzeń klasztoru - przestrzeń kultury. Piśmiennictwo - książkaedukacja, red. Joanna Pietrzak-Thébault, Łukasz Cybulski, Warszawa 20I7, s. 466-486. 
Kapele i instrumenty muzyczne odnotowano w monasterach, które zdecydowanie wyróżniały się wśród wszystkich klasztorów bazyliańskich. Były to przede wszystkim znane sanktuaria maryjne, do których pielgrzymowali nie tylko unici, ale również katolicy obrządku rzymskiego i prawosławni. W ciągu XVIII w. odbyły się przy tamtejszych cerkwiach uroczystości koronacyjne wizerunków maryjnych (Żyrowice, Chełm, Poczajów). W pozostałych ośrodkach znajdowały się ikony Bogurodzicy słynące cudami (Boruny, Supraśl, Uniów, Zahorów). W uroczystościach odpustowych brały udział kapele monasterskie lub też zapraszani byli muzycy przygrywający na instrumentach np. podczas procesji.

W Żyrowicach położonych w bazyliańskiej prowincji litewskiej już na początku XVIII w. w dni najważniejszych świąt i poprzedzających je wigilii orkiestra ulokowana na dzwonnicy monasterskiej dawała prawie dwugodzinne koncerty, złożone z pieśni religijnych i świeckich. Odsłanianiu i zasłanianiu cudownego obrazu Bogarodzicy towarzyszyły, zgodnie ze zwyczajami znanymi z kościołów łacińskich, dźwięki trąbek i bębnów ${ }^{61}$.

Szczególna oprawa muzyczna towarzyszyła uroczystościom koronacyjnym wizerunków Bogarodzicy przechowywanych w cerkwiach bazyliańskich w Żyrowicach i w Poczajowie. Pierwsza uroczystość odbyła się w I730 r. i zgromadziła tysiące wiernych, nie tylko unitów, lecz również łacinników. Z balkonu cerkwi żyrowickiej w tygodniu poprzedzającym koronację kapela odgrywała przede wszystkim pieśni maryjne ${ }^{62}$. Również koronacji ikony Bogarodzicy w Poczajowie, przeprowadzonej we wrześniu I773 r., towarzyszyła muzyka instrumentalna i wokalna, wykonywana przez samych zakonników, kapelę funkcjonującą przy tamtejszym monasterze oraz zespoły prywatne (kapela hrabiego Jana Amora Tarnowskiego) przybyłe na uroczystość. Obecność kapeli odnotowano zarówno w czasie trzydniowych przygotowań do obrzędu, podczas samych uroczystości, jak i w okresie jej oktawy. Podczas procesji kapele umieszczano na podwyższeniu, przeważnie na piętrach specjalnie wzniesionych bram triumfalnych, ozdobionych napisami zaczerpniętymi z Pisma Świętego, a odnoszącymi się do roli i znaczenia muzyki. Z kolei podczas nabożeństw kapele zajmowały miejsce na chórze muzycznym. Zadaniem muzyki instrumentalnej było „rozweselenie serc i umysłów tego narodu, który w wielkim mnóstwie zgromadzony, cały plac monasterowi przyległy, był zastąpił”. Podkreślano właśnie ożywczą moc muzyki i jej pozytywny wpływ na słuchaczy, wielokrotnie zaznaczając, że „granie muzyczne, i wdzięczne śpiewanie do wesołości serca i umysły pobudzało"63. Kapela każdego dnia grała przede wszystkim Litanię Loretańską, Pod Twoją obronę, pieśni maryjne. Przygrywała podczas nieszporów zarówno odprawianych zgodnie z obrządkiem wschodnim, jak i łacińskim. Towarzyszyła także śpiewanym Służbom Bożym i mszom świętym celebrowanym w ciągu prawie dwóch tygodni uroczystości.

63 Przestawna Góra Poczajowska, op. cit., k. I2Iv, I23. 
$\mathrm{Na}$ powitanie władyki chełmskiego i bełskiego Maksymiliana Ryłły kapela zagrała pieśń Wszedteś Biskupie do Kościota. Śpiewano hymny, np. hymn św. Ambrożego (Ciebie Boga wystawiamy), hymn św. Sofroniusza (Światto wdzięczne świętej chwaty) ${ }^{64}$.

Podczas obrzędu koronacyjnego koronator władyka Lubieniecki-Rudnicki zaintonował w języku cerkiewnosłowiańskim „pieśń sławną wschodniej Cerkwi”, poświęconą Bogarodzicy ${ }^{65}$. Zakonnicy w trakcie procesji śpiewali także „pienia święte na cześć Bogarodzicy osobliwie od świętego naszego Jana Damascena złożone, jak noty irmołoiczne wiodą, poważnie i nieskwapliwie" ${ }^{66}$. W czasie uroczystej liturgii koronacyjnej, odprawianej według obrządku wschodniego, „śpiewał częścią chór zakonny blisko wielkiego ołtarza stojący, częścią chór muzyczny, to jest tak, że czego chór muzyczny podług swojej sztuki nie mógł śpiewać, to poważnym głosem dobrani śpiewali mnisi”. Uroczysty charakter obrzędu i liturgii podkreślały kotły i bębny ${ }^{67}$. Z kolei podczas nieszporów śpiew diakona i chóru uzupełniała muzyka, wykonywana najprawdopodobniej na przenośnych organach (pozytywie) ${ }^{68}$.

Muzyka instrumentalna i wokalna towarzyszyła uroczystym procesjom, introdukcjom i odpustom parafialnym. W czerwcu I773 r. odbyła się introdukcja Bractwa św. Onufrego do cerkwi bazyliańskiej w Krystynopolu, którą uświetniała kapela zamkowa, wygrywająca melodie pieśni przeplatane śpiewem. Przez dwa dni po zakończeniu nabożeństw kapela oraz klarneciści grali melodie religijne, zaś zakonnicy śpiewali pieśni, stojąc na miejscu przygotowanym na bramie triumfalnej. Muzyka i śpiew rozlegały się długo w nocy. Muzyka instrumentalna towarzyszyła również odprawianym mszom św., zaś pomiędzy nimi „trąby, klarnety ganki grały”, zaś po ostatnim nabożeństwie odbył się koncert ${ }^{69}$.

Muzyka wokalna i instrumentalna obecna była podczas misji ludowych odprawianych przez bazyliańskich misjonarzy. Nabożeństwom misyjnym towarzyszyło śpiewanie pieśni, specjalnie dobranych do okoliczności. Autor podręcznika do prowadzenia misji bazyliańskich, Kornel Sroczyński, zalecał śpiew pieśni religijnych nie tylko w trakcie procesji odprawianych po mszy św., lecz także na początku nabożeństwa popołudniowego ${ }^{70}$. W Katechizmie krótko zebranym, przeznaczonym dla

64 Ibid., k. I22, I23, I29.

65 Ibid., k. I27. Słowa tej pieśni brzmiały: „Godna zaiste jest rzecz wielbić Cię Bogarodzico, która zawsze jest godna być błogosławioną i od wszelkiej zmazy wyjętą, która jesteś matką Boga naszego, nad Cherubinów sławniejsza i nad Serafinów bez porównania chwalebniejsza, któraś bez skazy Boga Słowo porodziła; Ciebie, która zaiste Bogarodzica, wielbimy”.

66 Ibid., k. I23-I23v.

67 Ibid., k. I29.

68 Ibid., k. I23: „Na jektenyię czyli kolektę, które jeden z diakonów śpiewał, chór muzyczny odpowiadał, który także Pieśń ś. Sofroniusza tę: Światło wdzięczne Świętey chwały, na narzędziu muzycznym przy głosach był grany".

69 CPAHL, f. 684, op. I, sp. 3067 - Księga bractwa św. Onufrego w Krystynopolu 1773, k. 43.

70 LNNB, f. 3, od. zb. I59 - Methodus Peragendi Missiones Apostolicas in Provincia Ruthena O.S. Basilii Magni I770, k. 75-IO3. 
misjonarzy bazyliańskich, Sroczyński umieścił dwanaście tekstów pieśni polecanych do śpiewania w czasie misji. Wśród nich pięć było spisanych w języku polskim, m.in. Boże w dobroci nigdy nie przebrany, Jezu w Ogrojcu mdlejący krwawy pot wylewajacy. Sroczyński określił czas i okoliczności ich wykonania, np. pieśń katechizmową zaczynającą się od słów: „Troyca Boh Otec, Boh Syn, Boh Duch Swiaty” śpiewać należało „rano i popołudniu przed katechizmem”7r. Podobną rolę jak Sroczyński w prowincji litewskiej odegrał o. Tymoteusz Szczurowski (I740-I8I2). Podczas misji Szczurowski wprowadzał elementy widowiskowości i barokowej pobożności opartej o wzorce zachodnie, których wyrazem były procesje z udziałem muzyki, trębaczy i flecistów, przy biciu dzwonów, strzelaniu z armat i moździerzy, a nawet pokazy fajerwerków ${ }^{72}$.

Przywołane przykłady wskazują, że muzyka instrumentalna towarzyszyła najczęściej nabożeństwom paraliturgicznym lub też przejściom procesyjnym. Koncerty kapeli monasterskich, grane najczęściej z dzwonnic, wypełniały czas w oczekiwaniu na nabożeństwo lub też towarzyszyły rozchodzeniu się wiernych.

Wykonywaniu muzyki instrumentalnej w klasztorach bazyliańskich sprzyjało prowadzenie przy nich szkół publicznych dla młodzieży zróżnicowanej obrządkowo. W ramach działalności kolegiów (Buczacz, Boruny, Humań, Żyrowice) używano instrumentów muzycznych podczas nabożeństw szkolnych, w teatrze szkolnym, albo podczas nauki muzyki i gry na instrumencie. W I777 r. w zaleceniach powizytacyjnych dla zakonników monasteru w Lubarze, przy którym funkcjonowało kolegium z konwiktem dla młodzieży świeckiej, zawarto polecenie utrzymywania „dyrektora [korepetytora i opiekuna konwiktorów - B.L.] na klawikorcie lub skrzypcach grać umiejącego"73.

W przeważającej większości cerkwi bazyliańskich zachowywano tradycję stosowania podczas liturgii tylko śpiewu. Obecność muzyki instrumentalnej w cerkwiach bazyliańskich w XVIII w. nie zawsze spotykała się z akceptacją ze strony zakonników. Wśród zaleceń powizytacyjnych pozostawionych przez prowincjała Symeona Bilinkiewicza w I824 r. dla klasztoru i kolegium w Humaniu znalazło się polecenie:

7I Katechizm krótko zebrany przedniejsze wiadomości do zbawienia potrzebne w sobie zawierający na Missjach Zakonu S. Bazylego Wielkiego Prowincyi Koronnej zwyczajny z dozwoleniem zwierzchności do druku podany, Lwów I768, k. I8-28v. Autorstwo pieśni katechizmowej przypisywano bazylianinowi prowincji litewskiej Tymoteuszowi Szczurowskiemu, zob.: Jurij Medwedyk, „Poczajowski Bohohtasnyk. Okoliczności powstania oraz źródła antologii ukraińskiej pieśni religijnej”, w: Polska - Ukraina. Iooo lat sąsiedztwa, t. 5, Miejsce i rola Kościoła greckokatolickiego w Kościele powszechnym, red. Stanisław Stępień, Przemyśl 2000, s. 352. Jednak badania Oksany Shkurgan podważają tę tezę, zob.: Oksana Shkurgan, „Repertuar pieśni nabożnych wykonywany w czasie misji bazyliańskich prowadzonych w Rzeczypospolitej w drugiej połowie XVIII w.", w: Zakon bazyliański na tle mozaiki wyznaniowej i kulturowej Rzeczypospolitej i krajów ościennych, red. Stanisław Nabywaniec, Sławomir Zabraniak, Beata Lorens, Rzeszów 2018, s. 297-299.

72 Dorota Wereda, „Działalność Tymoteusza Szczurowskiego na Podlasiu”, w: Zeszyty dziedzictwa kulturalnego, red. Karol Łopatecki, Wojciech Walczak, Białystok 2007, s. 6I.

73 Instytut Rękopisów Narodowej Biblioteki Ukrainy im. V.I. Vernads'kogo w Kijowie (dalej cyt. IRNBU), f. I - Literaturni materjali, nr IIO4 - Acta Monasterii Lubarensis Anno I769, k. 25v. 
Chór muzyczny jest wielką pomocą chórowi zakonnemu, ozdobą nabożeństwu, zachęceniem młodzieży do ćwiczenia się w tej sztuce i dlatego klasztor humański winien jest wdzięczność J.X. Rektorowi [o. Gracjanowi Mikulińskiemu - B.L.] za zaprowadzenie i utrzymanie muzyki kościelnej, lecz z drugiej strony postrzegliśmy, że w kościele osobliwie przy końcu i na początku nabożeństwa grane bywają różne tańce i marsze przyzwoitsze zgromadzeniom balowym lub ćwiczeniom wojennym, a niżeli domowi modlitw. Zalecamy zatem, aby na przyszłość oprócz Mszy Świętej granej wraz z śpiewakami żadne sztuki skoczne lub militarne w kościele nie były exelwowane. Tak nazwane ganki grane na dzwonnicy [sic] na zawsze się kassują ${ }^{74}$.

Elementy muzyki świeckiej coraz silniej wkraczające w sferę sacrum zostały tym samym wyeliminowane na rzecz śpiewu i gry organowej towarzyszącej liturgii. Zastanawiać się można, czy był to przejaw powrotu do tradycji chrześcijaństwa wschodniego czy wpływ nowych trendów w kulturze związanych z oświeceniowym odwrotem od widowiskowych ceremonii? Skłaniam się raczej ku tej drugiej opcji.

Jako przejaw latynizacji Cerkwi unickiej interpretowano wprowadzanie do świątyń tego obrządku organów. Bazylianie wiedli prym w ich instalowaniu w swych cerkwiach. W inwentarzu monasteru w Zahorowie, spisanym w 1752 r., wymieniono niewielki pozytyw ulokowany na chórze w cerkwi ${ }^{75}$. W kronice klasztornej w Zamościu odnotowano w I762 r. zamontowanie w tamtejszej cerkwi bazyliańskiej małych organów, wartych Iooo $\mathrm{złp}^{76}$. W przywileju dotyczącym utworzenia publicznego kolegium w Buczaczu, wystawionym w I754 r., starosta kaniowski Mikołaj Potocki nakazywał, że przy cerkwi bazyliańskiej pw. Krzyża Świętego: „organista i trębaczów dwóch w potomne czasy solariati być mają. Organista mszę jedną grywać, a trębacze okrom grywania w kościele, ile ukaże potrzeba co dzień rano i wieczór przed kościołem pieśń jaką nabożną wygrywać będą"77. W inwentarzu tej cerkwi z I769 r. nie odnotowano jednak organów. Wydaje się, że realizacja zapisu zawartego $\mathrm{w}$ akcie fundacyjnym nastąpiła połowicznie, tj. utrzymywano jedynie trębaczy ${ }^{78}$. W 1. 1758-6I prowadzono prace nad wybudowaniem organów w Żyrowicach ${ }^{79}$. W cerkwi bazyliańskiej w Zahajcach Małych organy dwunastogłosowe ufundował

74 Biblioteka Jagiellońska w Krakowie, rkps 4502 - Rękopism klasztorny XX. Bazylianów humańskich z ostatnich czasów przed kasata $w$ r. 1832, k. 49.

75 PAOT, f. 258 , op. 3 , spr. 1254, k. $274 \mathrm{v}$.

76 APL, zespół III/4 - Akta klasztorów greckokatolickich (bazylianów) woj. lubelskiego - zbiór szczątków zespołów - klasztor bazylianów w Zamościu, sygn. 29 - Diariusz albo partykularne notata monasteru Zamoyskiego, k. $8 \mathrm{v}$.

77 LNNB, f. 3, od. zb. 663/ - Przywilej Mikotaja Potockiego dla monasteru w Buczaczu, k. Io; Biblioteka Zakładu Narodowego im. Ossolińskich we Wrocławiu. Dział Rękopisów, akc. 62/89 - Acta Scholarum Buczacensium a primo Lapide Erectarum [... I I754, b. p. Mikołaj Potocki w I76I r. ufundował kapelę dla kościoła farnego w Buczaczu złożoną z kapelmistrza i dziesięciu kapelistów, którym wypłacano rocznie odpowiednio 600 złp i po 300 złp., por.: Pamiattki buczackie, zebrał i wyd. ks. Sadok Barącz, Lwów I882, s. 95-96.

78 CPAHL, f. 684, op. I, sp. IIO3, k. 4v; LNNB, f. 5, dz.I, od. zb. 6196, k. 22. Trębacze monasterscy byli obecni w 1758 r. podczas uroczystego ogłoszenia nowego prezesa Sodalicji Mariańskiej.

79 Por.: Irena Bieńkowska, Muzyka na dworze księcia Hieronima Floriana Radziwitta, Warszawa 2013, s. I26. 
tamtejszy superior o. Donat Jawłoszewicz po I784 r. ${ }^{80}$. W I802 r. organy dziesięciogłosowe odnotowano w Torokaniach ${ }^{81}$, zaś w I804 r. „małe” organy znajdowały się w cerkwi bazyliańskiej w Dermaniu ${ }^{82}$. W świątyni bazyliańskiej w Borunach w II poł. XVIII w. posługiwano się organami „sporządzonymi na I7 głosów” ${ }^{3}$. W I794 r. miejscowi zakonnicy zawarli kontrakt z kapelmistrzem nazwiskiem Chotkiewicz. Zobowiązał się on grać na organach mszę, litanię, godzinki oraz akatysty rano i wieczorem $^{84}$. W końcu XVII w. organy znajdowały się w cerkwi Zwiastowania NMP w archimandrii supraskiej ${ }^{85}$. W wizytacji z I829 r. opisano je jako „znacznej części pozłacany oraz sztukaterią na galerii jest organ snycerskiej roboty z dziesięciu głosami o dwóch miechach, malowany i ozdobiony" ". Pod koniec XVIII w. organy dziesięciogłosowe miały zostać umieszczone na chórze nowo wznoszonej cerkwi bazyliańskiej w Brześciu Litewskim ${ }^{87}$. Na obecność organów w cerkwiach w Poczajowie, Bracławiu oraz w cerkwi katedralnej pw. św. Jerzego we Lwowie powoływał się ks. Dariusz Ciołka ${ }^{88}$.

Wśród bazylianów prowincji koronnej był wykształcony organista Marcin Jasiński, pochodzący z ziemi lwowskiej (powiat żydaczewski), urodzony w I743 r., który w 1763 r. rozpoczął nowicjat bazyliański w Poczajowie. W trakcie swej posługi zakonnej pełnił funkcje zakrystianina, parocha oraz organisty ${ }^{89}$.

W cerkwiach bazyliańskich znajdowały się chóry muzyczne, przeznaczane na organy lub dla kapeli, lokalizowane głównie nad wejściem do świątyni. Chór dla kapeli w tym miejscu znajdował się w cerkwi pw. Trójcy Świętej w Kamieńcu Podolskimº. W Wicyniu odnotowano chór, ale nie było schodów, żeby na niego wyjść, bo jak zapisano, „na nim się nigdy nie gra, ani śpiewa, a kiedy podczas odpustu potrzeba grania wyciąga muzycy mieszczą się w chórze zakonnym za wielkim ołtarzem"9I. Chór muzyczny w nowo budowanej cerkwi bazyliańskiej w Krystynopolu według projektu polichromii, przygotowanego w I774 r. przez superiora tamtejszego klasztoru Kornela Sroczyńskiego dla malarza lwowskiego Stanisława Stroińskiego, miał być zdobiony scenami biblijnymi nawiązującymi do roli muzyki: „chóry anielskie

80 Wołyniak [J.M.A. Giżycki], Spis klasztorów unickich bazylianów w województwie wotyńskiem, Kraków I905, s. III.

8I Wołyniak [J.M.A. Giżycki], Siedziba bazylianów w Torokaniach, Kraków I906, s. 35.

82 Wołyniak [J.M.A. Giżycki], Spis klasztorów unickich, op. cit., s.I6.

83 D. Wereda, „Z dziejów sanktuarium”, op. cit., s. 204-205.

84 D. Ciołka, op. cit., s. 244.

85 I. Kuz’mins'kij, „Muzična praktyka v Suprasl's'komu monastiri”, op. cit., s. 4I.

86 M. Dobrowolska, op. cit., s. 6r3.

87 D. Wereda, „Bazylianie w Brześciu Litewskim w XVII-XVIII wieku”, Roczniki Humanistyczne 46 (2018), nr 2, s. II9.

88 D. Ciołka, op. cit., s. 203, 210, 245. W księdze finansowej monasteru w Poczajowie z lat siedemdziesiątych XVIII w. nie odnotowano wydatków związanych z funkcją organisty. Również wizytacje lwowskiej cerkwi katedralnej z lat sześćdziesiątych-siedemdziesiątych XVIII w. nie zawierały wzmianki o organach.

89 LNNB, f. 3 , od. zb. 436, k. 6.

90 APPD, Ławra Poczajowska, sygn. I2 - Inventarium generale monasterii Camenecensis Podoliae [...] I772, k. 28.

9I LNNB, f. 3, od. zb. 276 - Inwentarz monasteru wicyńskiego I772-I788, k. 3. 
z różnemi instrumentami muzycznemi albo Dawid przed arką Pańską skakający przy rezonancyi muzyki"92.

Organy i instrumenty muzyczne zostały odnotowane przede wszystkim w tych świątyniach bazyliańskich, które pełniły funkcje ważnych centrów religijnych i pielgrzymkowych. Częściej lokalizowane były na obszarach Wołynia, ziemi chełmskiej i województwa bełskiego oraz Litwy. Z porównania tradycji muzycznej bazylianów prowincji koronnej i litewskiej w XVIII w. wynika, iż ta druga szybciej i chętniej przyswajała sobie zachodnie zwyczaje muzyczne, w tym wprowadzanie do liturgii muzyki instrumentalnej.

Uniccy bazylianie wykonywali zarówno tradycyjny śpiew cerkiewny, jak i łacińską muzykę kościelną. Przy cerkwi bazyliańskiej pw. Ducha Świętego w Mińsku, gdzie przechowywano cudowną ikonę Bogurodzicy, dzięki fundacji unickiego archimandryty Augustyna Lubienieckiego z I733 r., wynoszącej Iooo talarów, utrzymywano chór. Śpiewał on podczas nabożeństw, zaś codziennie rano i wieczorem przed ikoną wykonywał łacińskie hymny maryjne Salve Regina i O gloriosa Domina ${ }^{93}$. Z kolei w I772 r. z okazji święta św. Józefa zakonnicy z monasteru w Wicyniu „śpiewali chorałem mszę łacińską"94.

Sami bazylianie rozwijali również muzykę przez twórczość związaną z pisaniem pieśni religijnych. Ich rola sprowadzała się głównie do stworzenia tekstu śpiewanego do istniejących już melodii. Rzadziej komponowali muzykę. Teksty były oryginalne lub tłumaczone z języka łacińskiego na język polski lub ruski. Można stwierdzić, że z dzieł literackich autorstwa bazylianów właśnie pieśni uzyskiwały największy odzew wśród prostego ludu i wiernych. Odgrywały również ważną rolę w duszpasterstwie ${ }^{95}$.

Znanym autorem pieśni religijnych był Tymoteusz Szczurowski. Na podstawie wspomnień rodzinnych Kazimierz Bartoszewicz napisał: „Ksiądz Szczurowski ułożył wiele pieśni nabożnych, które lud śpiewał nie tylko na Podlasiu i w całej diecezji chełmskiej, lecz i w diecezjach brzeskiej i włodzimierskiej" ${ }^{96}$. W celu upowszechnienia kultu św. Jozafata Kuncewicza Szczurowski opublikował teksty i melodie do pieśni o Męczenniku, które były śpiewane w miejscu przechowywania jego relikwii w Białej i propagowane wśród ludności unickiej. Jedna spośród pieśni wydanych

92 CPAHL, f. 684, op. I, sp. 3117 - Diariusz ihumena krystynopolskiego monasteru bazyliańskiego o organizowaniu i budowie cerkwi i monasteru w Krystynopolu $1763-1779$, k. $73 \mathrm{v}$.

93 Piotr Chomik, Kult ikon Matki Bożej w Wielkim Księstwie Litewskim w XVI-XVIII wieku, Białystok 2003, s. 76.

94 CPAHL, f. 684, op. I, sp. I204-Dziennik i historyczna wiadomość o monasterze w Wicyniu I764-I796, k. 23v.

95 Beata Lorens, „Bazylianie jako propagatorzy literatury łacińskiego kręgu kulturowego wśród społeczności unickiej w Rzeczypospolitej w XVIII wieku”, w: Między Wschodem a Zachodem. Prawostawie i unia, red. Marzanna Kuczyńska, Warszawa 2017 (= Kultura Pierwszej Rzeczypospolitej w dialogu z Europą. Hermeneutyka wartości II), s. 3I7.

96 Kazimierz Bartoszewicz, Dawna Biata na Podlasiu we wspomnieniach mego dziadka Adama (1792-1878). Przyczynek do dziejów miasta i gimnazjum, Biała Podlaska I928, s. I5; D. Wereda, „Działalność Tymoteusza Szczurowskiego", op. cit., s.7o. 
w zbiorze, zatytułowana Postuchajcie co zrobiła, powstała jeszcze w XVII w. i nie była autorstwa Szczurowskiego ${ }^{97}$. Być może pieśni dedykowane św. Jozafatowi bazylianin układał już na początku lat sześćdziesiątych XVIII w., będąc profesorem w kolegium bazyliańskim w Buczaczu. W 1. I76I-63 tamtejsi uczniowie kolegium z okazji święta bł. Jozafata śpiewali pieśni na głosy, poświęcone temu męczennikowi ${ }^{98}$. Pieśni autorstwa Szczurowskiego znalazły się również w innych jego publikacjach ${ }^{99}$. Szczurowski był też twórcą fundacji w kwocie 6 tys. złp, przeznaczonej na utrzymanie czterech chłopców, śpiewających przy relikwiach św. Jozafata ${ }^{100}$.

Ihumen (superior) monasteru w Krystynopolu, Kornel Sroczyński, z okazji wprowadzenia Bractwa św. Onufrego do tamtejszej cerkwi wydał we Lwowie okolicznościowy druk zatytułowany Chwata Boga Cudownego w Świętym Onufrym Krolewicu Perskim. Zamieścił w nim siedem pieśni, w tym sześć ułożonych przez siebie dedykowanych św. Onufremu, św. Bazylemu Wielkiemu, św. Mikołajowi, Matce Bożej oraz Panu Jezusowi (dwie) ${ }^{\text {Ior }}$.

W 1759 r. superior w Wicyniu Sylwester Łaszczewski napisał pieśń poświęconą Matce Boskiej Wicyńskiej oraz ułożył modlitwę do niej. Treść pieśni, składającej się z dwunastu zwrotek, spisanej w języku polskim, nawiązywała do historii cudownego obrazu. Śpiewano ją na melodię popularnej w XVIII w. pieśni Boże $w$ dobroci ${ }^{\mathrm{IO} 2}$. Z kolei podczas pobytu w Hoszczy, gdzie pełnił funkcję rektora kolegium w I768 r., Łaszczewski napisał Pieśń o Najświętszej Matce Hojskiej, składającą się aż z siedemnastu zwrotek, ułożonych w języku polskim. W tym przypadku melodię oparł na pieśni ruskiej Preczystaia Diwo Maty, poświęconej Matce Boskiej Podkamienieckiej ${ }^{\text {Io3. }}$

Pieśni pisał również Hilarion Łątowski, o którym wiadomo, iż posiadał pewne przygotowanie muzyczne, bowiem grał na skrzypcach. W połowie lat siedemdziesiątych XVIII w. był on superiorem monasteru w Ułaszkowcach, gdzie napisał dwie pie-

97 D. Wereda, „Kult Jozafata Kuncewicza”, op. cit., s. 94; Pieśni na cześć św. Jozafata arcybiskupa potockiego utożone przez ks. Tymoteusza Szczurowskiego, Kraków b.d. (kolejne wyd. w Rzymie w i868 r. z okazji kanonizacji Jozafata Kuncewicza). Dwie pieśni zostały opatrzone zapisem nutowym na głos i organy, zob.: Maria Pidłypczak-Majerowicz, „Cunceviana w zbiorach Ossolińskich”, Annales Universitatis Paedagogicae Cracoviensis Folia 47 Studia ad Bibliothecarum Scientiam Pertinentia 5 (2007) s. 3-II, zob. s. 7-8.

98 LNNB, f. 5, dz. I, od. zb. 6196, k. 49v, I09.

99 Oksana Shkurgan, „Pieśni nabożne wydane przez o. Tymoteusza Szczurowskiego w kontekście repertuaru wykonywanego w środowiskach rzymskokatolickich i unickich w Rzeczypospolitej Obojga Narodów”, Rocznik Lituanistyczny I (2015), s. 197-218.

Ioo D. Ciołka, op. cit., s. 27 I.

IoI Oksana Shkurgan, „Pieśni ihumena krystynopolskiego o. Kornela Sroczyńskiego w nowo odnalezionym druku Chwata Boga Cudownego w Świętym Onufrym (Lwów I773)”, Muzyka 62 (2017) nr I, s. 90-I24.

IO2 CPAHL f. 684, op. I, sp. I202 - Rękopiśmienne teksty pieśni i modlitw I759-I768, k. IV-3v. Współcześnie pieśń do Matki Bożej Wicyńskiej popularyzuje środowisko dawnych mieszkańców Wicynia, zob.: „Uratują od zapomnienia”, Niedziela (edycja Bielsko-Żywiecka) 33 (2013) nr 50, s. 7.

I03 CPAHL, f. 684, op. I, sp. I202, k. 5v-6v. Melodia pieśni wybrana przez Łaszczewskiego była bardzo popularna w XVIII stuleciu, zob. Jurij Medwedyk, „Z dziejów ukraińskiej pieśni religijnej”, w: PolskaUkraina. Iooo lat sasiedztwa, op. cit., t. 2, s. 40I; tegoż, „Poczajowski Bohohtasnyk”, op. cit., s. 35 I. 
śni. Pierwsza - Pieśń o NMP w tutejszym obrazie taskami stynącym napisana z cudów i dowodów powstała I XI I773 r., zaś druga - Pieśn o świętym Janie Krzcicielu taskami stynącym $w$ tutejszej skale - pochodziła z I776 roku. Obie zanotował w języku ruskim, ale łacińskim alfabetem. Pieśń o św. Janie Chrzcicielu należało śpiewać na melodię hymnu Omni die dico Mariae, spopularyzowanego na terenach Rzeczypospolitej dzięki św. królewiczowi Kazimierzowi Jagiellończykowi, którego był ulubioną modlitwą. Było to znowu odwołanie do tradycji łacińskiej ${ }^{104}$. Z ikoną Bogarodzicy uznaną za cudowną a przechowywaną w monasterze w Ułaszkowcach związane były pieśni maryjne w języku polskim i ruskim (ukraińskim) spisane wraz z litanią i godzinkami do NMP w XIX w. ${ }^{\text {ios. }}$.

Pieśni tych nie udało się odnaleźć w śpiewniku wydanym w I790 r. w drukarni poczajowskiej. Znalazły się tam natomiast inne, których autorami byli bazylianie, niewymienieni jednak z nazwiska. Wśród tych utworów znalazło się piętnaście pieśni, pisanych w języku polskim i ruskim, poświęconych Matce Bożej czczonej w obrazach cudownych i słynących łaskami w monasterach prowincji koronnej (Poczajów, Zahorów, Poddębce, Krzemieniec, Podhorce, Białostok, Tryhory, Zahajce Małe, Zimno, Pohynki) oraz siedem pieśni dedykowanych świętym (św. Jan Chrzciciel, św. św. Piotr i Paweł, św. Bazyli Wielki, św. Onufry Pustelnik, św. Jozafat Kuncewicz) ${ }^{106}$. Według Jurija Medwedyka autorem dwóch pieśni drukowanych w śpiewniku był Adrian Szubowicz, bazylianin z Owrucza ${ }^{107}$. Pieśni, proste w formie i treści, w sposób zrozumiały i przystępny informowały o życiu i świętości patronów oraz cudownych zdarzeniach związanych z ikonami czczonymi w cerkwiach monasterskich. Według znawców tej problematyki pieśni nie tylko były popularne w środowisku unitów, lecz także śpiewane przez prawosławnych. Bazylianie tłumaczyli również na języki polski i ruski słowa łacińskich hymnów, wykonywanych w kościołach, np. hymn De vanitate mundi ( $O$ próżności świata) i pieśń Moriendum hoc est certum (Umrzeć trzeba, to rzecz pewna) ${ }^{\mathrm{I0} 8}$.

Działalność duszpasterska prowadzona w XVIII w. wymusiła na bazylianach wyjście poza ramy tradycyjnej muzyki liturgicznej. Udział w uroczystych celebrach ludności różnych obrządków katolickich skłaniał do wprowadzania muzyki instrumentalnej i pieśni paraliturgicznych. Muzykę instrumentalną wykorzystywano głównie w większych centrach religijnych, przede wszystkim w sanktuariach maryjnych.

\footnotetext{
I04 CPAHL, f. 684, op. I, sp. 3022 - Historyczna wiadomość o monasterze w Utaszkowcach I746-I85I, k. IO, I3v. ios Archiwum Państwowe w Przemyślu, Kapituła Greckokatolicka w Przemyślu, sygn. 9403 - Wiadomość o cudownym obrazie Nayświetszey Maryi Panny Matki Boskiey nieba i ziemi Królowey [...], s. 72-I43. I06 Zob.: Bogoglasnik. Pisni blagogoviiny, Počaiv I790, k. I-296.

IO7 Jurij Medvedik, „Ukrains'ki duchovni pisni u l'vivs'kih pol's'komovnih starodrukah XVIII st.”, Musica Galiciana 6 (200I), s. I7. Miał on być autorem tekstu pieśni w języku ruskim na święto Przemienienia Pańskiego (nr 68) oraz w języku polskim Ach mój Boże (nr 220). W śpiewniku nie wymieniano jednak nazwiska autora.

I08 Bogoglasnik, op. cit., k. 25I-253, 274-275v.
} 
Jej stosowanie było nieraz warunkowane wolą fundatorów i zapotrzebowaniem społecznym związanym z kulturą baroku. Przy monasterach zakładano zatem kapele uświetniające uroczystości religijne, ale również pozyskujące dochody z racji świadczenia usług muzycznych instytucjom i osobom prywatnym. W cerkwiach bazyliańskich montowano organy, obce tradycji wschodniej. Bazylianie byli autorami tekstów pieśni śpiewanych podczas uroczystości religijnych oraz tłumaczami na język polski i ukraiński hymnów łacińskich. Zaobserwowane tendencje dotyczyły kilkunastu monasterów wyróżniających się wśród placówek bazyliańskich, jednak w zdecydowanej większości cerkwi klasztornych podczas niedzielnej i codziennej liturgii posługiwano się muzyką wokalną związaną z tradycją wschodnią.

\section{MUSIC IN THE BASILIAN MONKS' PASTORAL WORK IN THE I8TH-CENTURY POLISH-LITHUANIAN COMMONWEALTH}

The Basilian monks were responsible for pastoral work in their own parishes, served in sanctuaries visited by large numbers of the faithful, and conducted 'folk missions' among the populations in the eastern parts of the Polish-Lithuanian Commonwealth. Music, both vocal and instrumental, played an eminent role in their activities. They were the ones who introduced instrumental (mainly organ) music in the Eastern (Uniate) Church. In the 2nd half of the I8th century, the instrument was more and more frequently to be found in Uniate churches. Analyses prove that the organ was used in monasteries of the Lithuanian province, especially in cities and in Lithuania, Volhynia as well as the Chełm Eparchy. It was introduced less frequently in the southeast of the Commonwealth - the Ruthenian and Podolian provinces. Apart from the organ, the churches also had wind and string instruments at their disposal, but the latter were mostly used during parish feasts related to indulgencies. Monasteries had their vocal-instrumental ensembles. In the I8th century, they performed music in at least six of them (Vilnius, Chełm, Zhyrovichy, Pochaiv, Univ, Supraśl), while the presence of music instruments is recorded for five others (Zahorów, Uman, Biała, Buchach, and Baruny). The monks also used the services of ensembles established in Roman Catholic churches or at aristocratic houses. They cultivated traditional Eastern church singing, but at the same time familiarised the faithful with Latin songs and hymns translated into Polish or Ruthenian (Ukrainian). The monks themselves also wrote texts of religious songs for various occasions. The compositions applied by I8th-century Basilian monks in their pastoral work combined elements of traditional Eastern Church music with influences from Western Baroque music. 
Słowa kluczowe / keywords: bazylianie / Basilian monks, muzyka / music, kapela / ensemble, organy / organ, instrumenty muzyczne / music instruments, pieśni / songs

Dr hab. Beata Lorens, profesor nadzwyczajny w Zakładzie Historii Nowożytnej i Dziejów Kościoła Instytutu Historii Uniwersytetu Rzeszowskiego. Jest autorką trzech książek, w tym m.in. monografii Bazylianie prowincji koronnej w latach I743-I780 (Rzeszów 20I4), współredagowała cztery publikacje zbiorowe, m.in. Zakon bazyliański na tle mozaiki wyznaniowej i kulturowej Rzeczypospolitej i krajów ościennych (Rzeszów 2018), opublikowała ponad siedemdziesiąt artykułów naukowych. Jest członkiem Polskiego Towarzystwa Historycznego, Rady Naukowej Muzeum Regionalnego w Brzozowie oraz rad naukowych czasopism polskich i ukraińskich. Jej zainteresowania badawcze koncentrują się na stosunkach religijno-społecznych na pograniczu etnicznym polsko-ruskim (ukraińskim) w czasach nowożytnych, zagadnieniach związanych z dziejami Kościoła oraz historią regionalną. blorens@poczta.fm

\section{Recently published books by Liber Pro Arte}

Ars musica and Its Contexts in Medieval and Early Modern Culture edited by Pawet Gancarcayle.

Music Migration in the Early Modern Age: Centres and Peripheries - People, Works, Styles, Paths of Dissemination and Influence edited by Jolanta Guzy-Pasiak \& Aneta Markuszewska

iswydawnictwo@ispan.pl

\section{Nowe wydawnictwa Instytutu Sztuki PAN}

Bronisława Wójcik-Keuprulian. Korespondencja do Szwajcarii. Listy do Henryka Opieńskiego (1925-37) i Ludwika Bronarskiego (1929-38) opracowanie, wstep $i$ komentarze Matgorzata Sieradz.

Zygmunt Mycielski - Andrzej Panufnik. Korespondencja Część 2: Lata 1970-1987

opracowanie, wstep i komentarze Beata Bolestawska-Lewandowska

www.ispan.pl

iswydawnictwo@ispan.pl 